of culture, aroused no little interest both in Great Britain and, more especially, in the United States by his well-balanced handling of the subject. Dr. Harrison will be succeeded at the Horniman Museum by Dr. L. W. G. Malcolm, who since 1935 had been a member of the inspectorate of the London County Council, and has been engaged in organizing arrangements for the further utilization of the resources of the museum collections of London by the pupils of London schools as part of the educational curriculum. Dr. Malcolm, on coming to England from Australia, was trained as an anthropologist at Cambridge by Dr. Haddon and in Germany. He was formerly curator of the ethnographical collections in the Bristol Municipal Museum and later conservator of the Wellcome Historical Medical Museum.

\section{British Pharmaceutical Conference at Liverpool}

THE seventy-fourth British Pharmaceutical Conference was held on July 26-30 at Liverpool, this being the fourth occasion upon which Liverpool has given hospitality to the Conference. Mr. T. E. Lescher delivered his presidential address entitled "Pharmacy Today-Its Responsibilities" the main theme of which was the contrast between the important contribution made by pharmaceutical research to the national well-being and the lack of official recognition of this service. Many painstaking chemical, pharmaceutical and biological investigations, said $\mathrm{Mr}$. Lescher, have resulted in placing the treatment of disease increasingly on a scientific basis by the discovery of specific remedies which remove the cause of disease rather than alleviate its symptoms and, of almost equal importance, have, where necessary, enabled these remedies to be taken in a form which does not cause the patient to rebel against them. In view of such achievements, it is surprising that the pharmacist has not received the recognition which his work and responsibilities deserve and which his Continental confrère enjoys. The present system of allowing anyone to handle the majority of drugs and medicines on payment of a five-shilling licence annually encourages the exploitation of the public by the distribution of 'cure-alls' without the slightest guarantee of any knowledge of their properties on the part of the vendor. The official attitude in its latest form is seen in the report of the Select Committee on Medicine Stamp Duties, which recommends what is in effect a sales tax on medicines if claimed to be beneficial to health. It is almost unbelievable that a body of public men should suggest that the State is justified in taxing medical substances used in illhealth.

\section{Julaber's Grave, Kent}

THE mound or barrow known as Julaber's Grave or Jullieberrie, at Chilham, near Canterbury, has long been an object of interest to archæologists and others, mainly perhaps on account of the lack of precise evidence of its character and age. It is thought to be neolithic, dating from about 2000 B.c. Its excavation has been undertaken by Mr. R. F. Jessup, the author of the volume on Kent in the County Archæology series, on behalf of Sir Edmund Davis of Chilham Castle. The barrow is $144 \mathrm{ft}$. long, by $45 \mathrm{ft}$. wide. In the initial operations, which were carried out last year, the course was traced of the ditch running round the mound, from which its material was taken. In the investigations of the present season, a longitudinal section has been cut, following the ditch, which has revealed the construction of the barrow above the original chalk surface. This shows a darker section where the original turves form a core and a loose rubble of chalk from the ditch. A par. ticularly interesting find is recorded (The Times, July 31 ). This is a large circular burial in the side of the mound, probably of Roman date. It shows the cutting through the neolithic layer and the careful replacement of the mixed soil. This is held to support the view that the barrow is the burial place of Laberius Durus, one of Cresar's generals of the second invasion, of whose name, "Julaber" is thought to be a local corruption. Another interesting find is that of three skeletons at the edge of the ditch at the south end of the mound, three feet below the surface. These have been ascribed to Romans of the third century of our era. They are the remains of a large. welldeveloped man, a child and a girl. The child's bones were extremely fragile and disintegrated at once, but the small drinking vessel, a platter of rough coarse black ware, and the fibula, which had held the shroud together, were recovered. The girl's remains were fairly well preserved, but those of the man were in an excellent state of preservation.

\section{Angmering Roman Villa}

AN appeal is issued for funds for the excavation of the extensive Roman villa site near the old village of Angmering, Sussex. The site is situated in the flat meadows which lie between the downs and the sea, beside a Roman road, still to be traced with prob. ability as a farm track between Lyminster and Poling, and as the footpath from Poling to Angmering across the Black Ditch. The site first attracted the attention of archæologists in 1819, when a Roman bath was discovered, with hypocaust, sudarium and sewers. This bath was rediscovered at the beginning of the present year, and the whole bath building is now being uncovered by Mr. R. C. Sherrif and the Littlehampton Archæological Society, with the co-operation of the Sussex Archæological Society, under the direction of Miss Leslie Scott with Dr. R. E. Mortimer Wheeler acting as advisory director. The bath building comprises a dozen or more rooms, some with hypocausts, grouped around a cold-water tank. The building appears to stand by itself, surrounded by a beaten chalk causeway, flanked on the west side by a ditch. It was built in the latter part of the first century, and is interesting both on account of its early date and for the richness of its internal decoration. Beside the usual painted wall plaster and window glass, common on such sites, there is evidence that some walls were faced with slabs of different coloured stones. The bath building was destroyed in the middle of the second century; 